Bot. Mag. Tokyo 79: 152-155 (April 25, 1966)

\title{
Mitoses in Hansenula and Debaryomyces
}

\author{
by Akira Yuasa*, Masako Osumi** and Naoko FuJIKI**
}

Received December 21, 1965

Yuasa et al. $(1965,1965)^{1,2)}$ already observed $\mathrm{n}=4$ in Saccharomyces cerevisiae and also $\mathrm{n}=4$ in Wickerhamia fluorescens. They advocated that the basic number of the so-called yeast-cells was 2 .

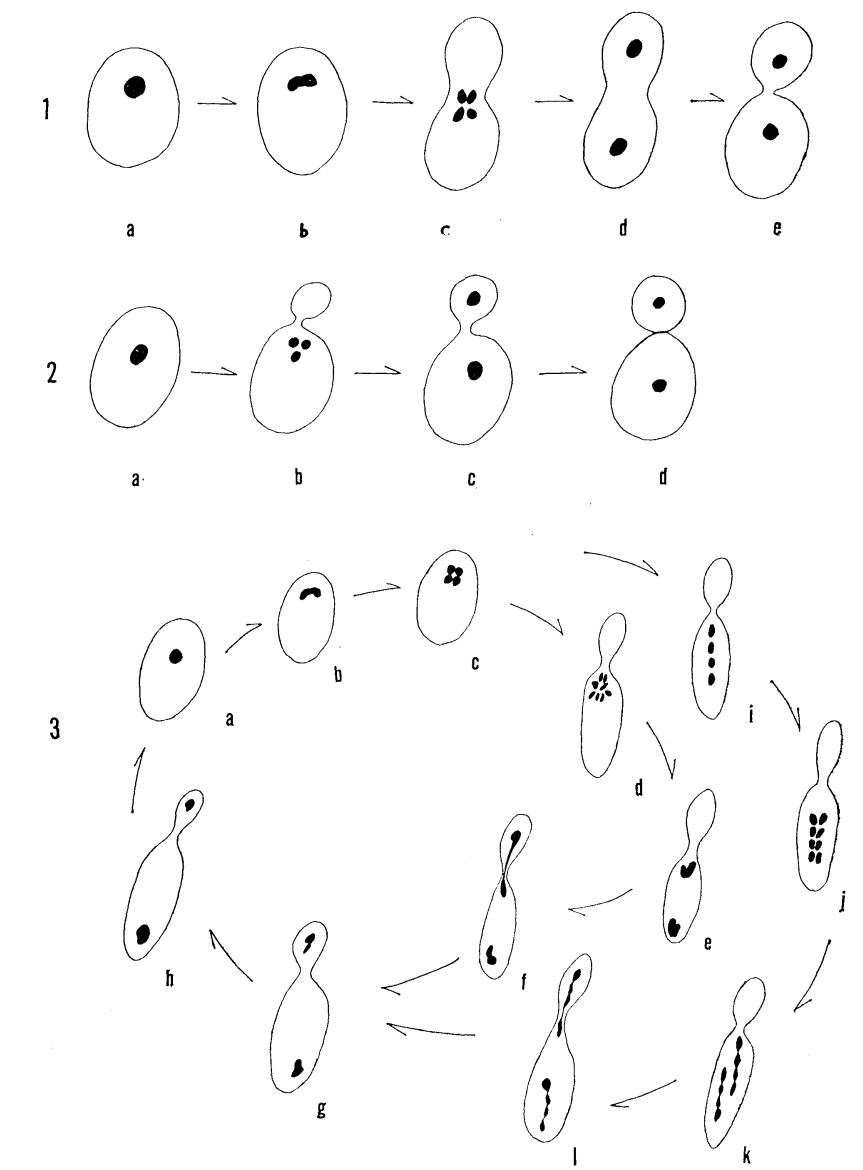

Fig. 1. Mitosis in Hansenula mrakii. a, resting stage; b, prophase; c, metaphase; d, anaphase; e, telophase.

Fig. 2. Mitosis in H. jadinii. a, resting stage; b, metaphase; c, telophase; d, after nuclear division, two cells appear by budding.

Fig. 3. $\mathrm{a} \sim \mathrm{h}$, mitosis and cell division by budding in Debaryomyces arteielli. a, resting stage; $b$, prophase; c, metaphase; $d$, anaphase; e, telophase; $f$, one daughter nucleus enters the bud; g, two cells appear by budding. $\mathrm{i} \sim 1$, four chromosomes arrange themselves to be parallel to the longitudinal axis of the cell and divide.

* Department of Biology, College of General Education, University of Tokyo, Komaba, Meguro, Tokyo.

** Department of Biology, Faculty of Home Economics, Japan Women's University, Mejiro, Bunkyo, Tokyo. 

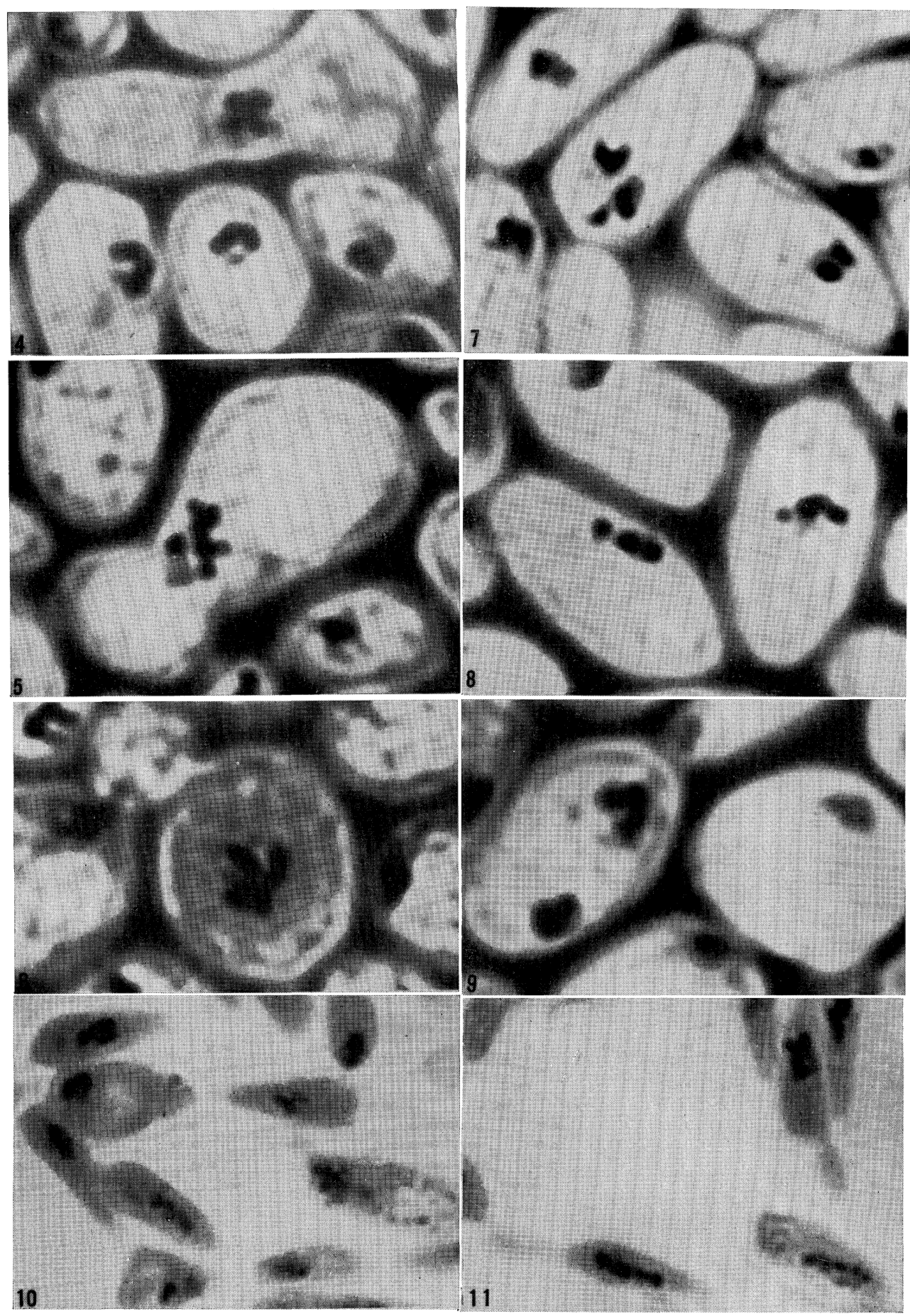

Figs. 4 6. Mitosis in Hansenula mrakii. ca. $\times 9,700.7 \sim 9$, mitosis in $H$. jadinii ca. $\times 9 ; 700.10$ and 11, mitosis in Debaryomyces arteielli. ca. $\times 5,000$. 
In 1962 Yoneda $^{3)}$ confirmed $\mathrm{n}=4$ in Torula, $\mathrm{n}=3 \sim 4$ in Lipomyces starkeyi and Robinow (1961) $)^{4)}$ observed $\mathrm{n}=4 \sim 6$ in L. lipofer.

In the present study, Hansenula mrakii, H. jadinii and Debaryomyces arteielli were used as the materials. The cells were fixed with Carnoy's fluid and stained with Giemsa's or gentian violet solution. Sometimes, the cells were treated with $10 \%$ aqueous solution of perchloric acid for $17 \mathrm{hr}$. at $4^{\circ}$ after fixed with Carnoy's fluid, and then stained with Giemsa's or gentian violet solution. Feulgen's nuclear staining method was also used.

By these methods, the spindle can not be observed clearly. For this purpose, other methods should be used.

In the present study, four chromosomes were observed in Hansenula mrakii, and it was confirmed that the mitosis occurred in the central part of the cell and that the

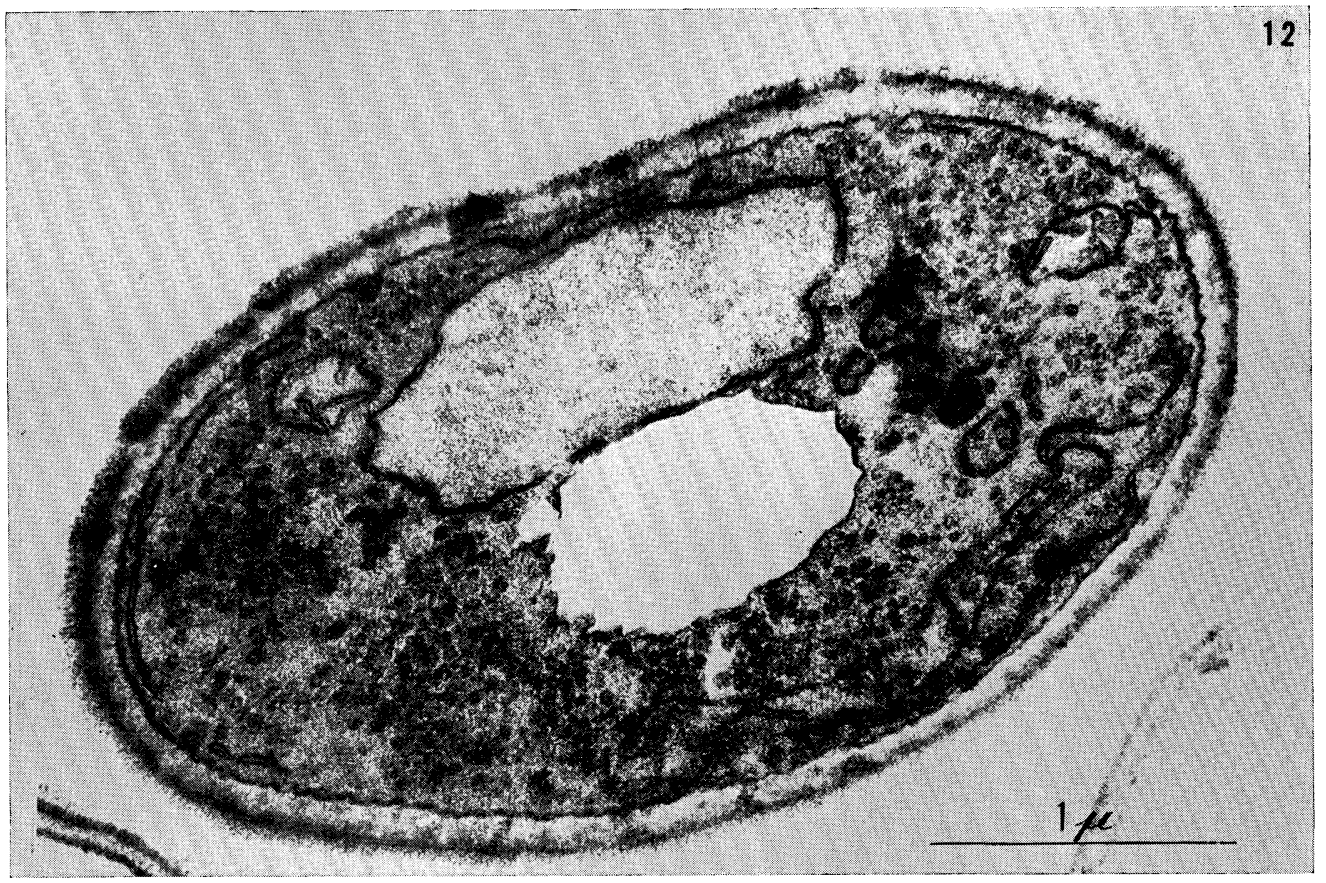

Fig. 12. Electron-micrograph of thin-section of cell in Hansenula mrakii.

cell divided by fission, containing one daughter nucleus respectively (Figs. 1, a e 4, $5,6)$.

In the case of $H$. jadinii, the haploid number of chromosomes is three (Figs. 7, 8). One daughter nucleus enters the bud after mitosis and the cell divided by budding (Figs. 2, a $\sim d, 7,8,9$ ). In this case, it is thought that three chromosomes have been induced by non-disjunction or by deletion. But the detailed mechanism should be studied in future by cytological and genetic methods.

In Debaryomyces arteielli, four chromosomes appear at metaphase and the cell divided by budding (Figs. 3, a f, 10, 11). Sometimes, the four chromosomes arrange themselves to be parallel to the longitudinal axis of the mother cell, and every chromosome divides longitudinally. So at this stage, two rows of the four chromosomes appear, and one row enters the bud to form a daughter nucleus (Fig. 3, i $\sim 1$ ). 
This type of division was also shown by Ramirez and Miller (1962) ${ }^{5)}$ in Saccharomyces cerevisiae.

By electron-microscopical study, no differences were found in the thin-sectioned cells of Hansenula mrakii, H. jadinii and Debaryomyces arteielli (Figs. 12, 13).

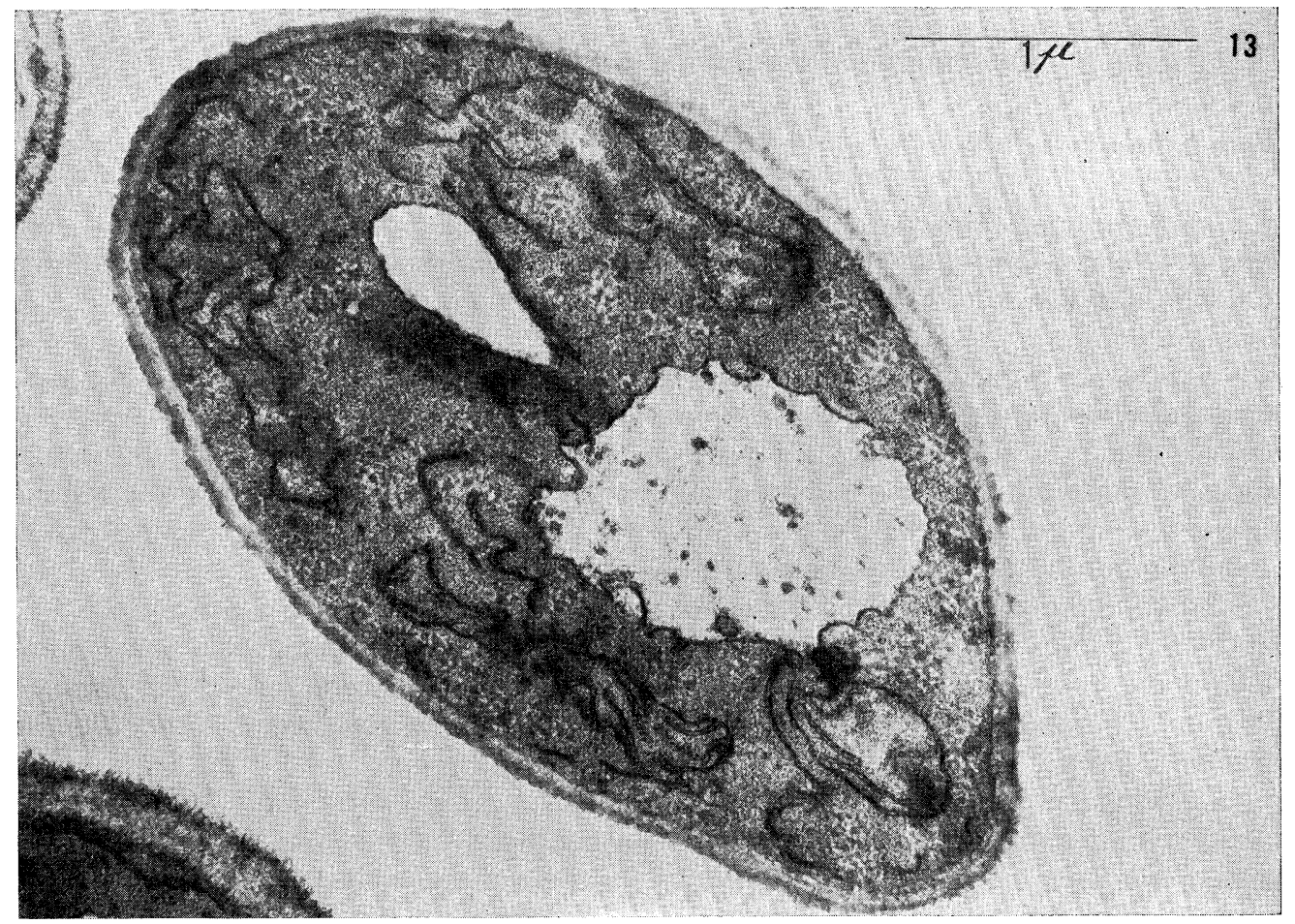

Fig. 13. Electron-micrograph of thin-section of cell in Debaryomyces arteielli.

\section{References}

1) Yuasa, A., Jap. Jour. Bot. 19: 1 (1965). 2) Yuasa, A., Soneda, M., Osumi, M. and Sumiyasu, M., Jap. Jour. Gen. 40: 21 (1965). 3) Yoneda, Y., Cytologia 28: 131 (1963). 4) Robinow, C. F., J.B.B.C. 9: 874 (1961). 5) Ramirez, C., and Miller, J. J., Canad. Jour. Microbiol. 8: 603 (1962).

摘 要

湯浅 明*.大隅正子**.藤木尚子**: Hansenula と Debaryomyces の有糸分裂

1. コウボ類の Hansenula mrakii では $\mathrm{n}=4$ で，細胞は二分法でわれるが，H.jadinii ではn=3で, 細胞は出芽法でわれる。 $\mathrm{n}=3$ は $\mathrm{n}=4$ から誘導されたものと思われる。

2. Debaryomyces arteielli では, $\mathrm{n}=4$ で，細胞は出芽法でわれる.ときに Ramirez and Miller (1963)が示したように，染色体が四つたてに並び，それぞれ分裂して，4染色体の 2 列となり，1列は芽に， 残りの 1 列は細胞に残ることも見られた。（*東京大学教養学部生物学教室, **日本女子大学家政学部生物 学教室) 